\title{
PROCESS CHARACTERISTICS OF HYDRAULIC LEGS EQUIPPED WITH SAFETY VALVES AT DYNAMIC LOAD CAUSED BY A MINING TREMOR
}

\section{CHARAKTERYSTYKI PRACY STOJAKÓW HYDRAULICZNYCH Z ZAWORAMI BEZPIECZEŃSTWA PRZY OBCIĄŻENIU DYNAMICZNYM WYWOLANYM WSTRZĄSEM GÓROTWORU}

The article presents process characteristics of hydraulic legs, a powered roof support and an individual roof support that are equipped with pressure relief valves and additional safety valves protecting the legs against dynamic loads caused by mining tremors.

A two-telescopic hydraulic leg $\phi 330$ type was tested using dynamic pile testing, equipped with a valve bank with pressure relief valve and an additional safety valve. The tests included the following models of safety valves described in references (Gwiazda, 1997; Irresberger et al., 2008) :

- slide-piston with a roller spring,

- seat-cone with gas spring,

- slide-piston with a roller spring,

- two-stage valve (a control valve and a main valve connected in one support).

Using pressure charts in time function it is possible to determine how fast the amplitudes of pressure increase with the $h$ height of a ram increase, thereby, $E_{k}$ kinetic energy of ram's stroke and $p$ momentum impacting the leg equipped with the valve. Maximum pressure in the leg with the slide-piston valve raised to $64 \mathrm{MPa}$ (with impact mass drop at $h=0.25 \mathrm{~m}$ ) up to $129 \mathrm{MPa}(h=0.3 \mathrm{~m})$ i.e. by $100 \%$.

Pressure increase to $p_{\max }=158 \mathrm{MPa}$ was noted during a test of the slide-piston leg equipped with the valve and with a drop of $h=0.5 \mathrm{~m}$ This poses a great hazard that can destroy the valve and therefore cause a loss of load-bearing capacity.

Conducted research of SHC hydraulic legs of an individual roof support showed that (Pytlik \& Pacześniowski, 2012; Pytlik \& Rabsztyn, 2011) quick relief valves had higher efficiency than standard valves mounted in SHC legs, which resulted in lower pressure in the leg by $7 \mathrm{MPa}$. It has an essential importance for stability of leg's cylinder and its sealing. The test of the leg with a valve battery was based on its dynamic load impacted by a ram (impact mass) of $m_{1}=4,000 \mathrm{~kg}$ relieved at the leg placed between a cross-bar of $m_{2}=3,300 \mathrm{~kg}$ and post's foundation. Recording of $\boldsymbol{p}$ pressure of the fluid in its space under piston was made with sampling frequency of $9.6 \mathrm{kHz}$,

Moreover, the research also included test of the same type of SHC leg with BZG-2FS battery (equipped with gas spring) using ram's mass of $m_{1}=2,0000 \mathrm{~kg}$ and the cross-bass of $m_{2}=6,600 \mathrm{~kg}$. The leg transferred the load, stroke type, of $E_{k}=29,5 \mathrm{~kJ}$ kinetic energy without any damages. A time-lapse analysis of photos showing the opening moment of the safety valve indicated that its opening had taken place $8 \mathrm{~ms}$ after the moment when the leg was impacted and indicated propagation of the hydraulic fluid

* CENTRAl mining InStitUTe, PlaC GWARKÓW 1, 40-166 KATOWICE, POLAND.

E-MAIL: a.pytlik@gig.eu; ja.pytlik@gmail.com 
stream's front with maximum velocity of about $60 \mathrm{~m} / \mathrm{s}$, and maximum momentary intensity of fluid flowing through a bypass valve amounted to $Q_{c \max }=683 \mathrm{l} / \mathrm{min}$.

The tests of work characteristics of safety valves (Pytlik, 2013, 2014) included valves with M40×2 terminal thread of the following designs:

- slide-piston - with three rows of fluid outlets,

- slide-piston - with two rows of fluid outlets,

- seat-cone - with a single row of fluid outlets.

The tests of valves were conducted on the basis of capacity research methodology based on fluid increase of fluid stream caused by mass stroke impacting the leg equipped with the valve, up to twice the working pressure adjusted value of the valve. Such test simulates dynamic load of the hydraulic leg with the valve during mining tremors. Tests results of capacity and valve opening time may be used to determine yielding of an individual powered roof support and to optimize valve construction in order to improve capacity and working time. On the basis of carried out research concerning momentary intensity of $Q_{c}$ flow of safety valves with M40×2 terminal, it may be stated that the valves are characterised by a high level of capacity, presented on charts, and short working time -3 up to $5 \mathrm{~ms}$. The best technical parameters had a prototype seat-cone valve.

Keywords: powered roof support; individual roof support; hydraulic legs; bypass valves; safety valves; capacity

W artykule przedstawiono charakterystyki pracy stojaków hydraulicznych, obudowy zmechanizowanej i indywidualnej, wyposażonych w zawory przelewowe oraz dodatkowe zawory bezpieczeństwa chroniące stojaki przed przeciążeniami dynamicznymi spowodowanymi wstrząsami górotworu.

Badaniom przy obciążeniu dynamicznym, w kafarowym stanowisku badawczym, poddano dwuteleskopowy stojak hydrauliczny $\phi 320$, wyposażony w stojakowy blok zaworowy z zaworem przelewowym oraz dodatkowym zaworem bezpieczeństwa. W badaniach wykorzystano zawory bezpieczeństwa opisane w literaturze (Gwiazda, 1997; Irresberger i in., 2008) o konstrukcji:

- suwakowo-tłokowej ze sprężyną walcową,

- gniazdowo-stożkowej ze sprężyną gazową,

- suwakowo-tłokowej ze sprężyną walcową,

- zaworu dwustopniowego (zawór sterujący oraz zawór główny połączone w jednej obudowie).

Na podstawie wykresów ciśnienia w funkcji czasu można określić jak szybko rosną amplitudy pików ciśnienia ze wzrostem wysokości $h$ spadku bijaka, a tym samym energii kinetycznej $E_{k}$ udaru bijaka i pędu $p$ w stojak z zaworem. Maksymalne ciśnienie w stojaku z zaworem o konstrukcji suwakowo-tłokowej wzrosło z ciśnienia o wartości $64 \mathrm{MPa}$ (przy wysokości spadku masy udarowej $h=0,25 \mathrm{~m}$ ) do $129 \mathrm{MPa}(\operatorname{przy} h=0,3 \mathrm{~m})-\mathrm{tj}$. o $100 \%$.

Podczas badanie stojaka z zaworem o konstrukcji suwakowo-tłokowej, przy wysokości spadku $h=0,5 \mathrm{~m}$ stwierdzono wzrost ciśnienia do wartości $\boldsymbol{p}_{\max }=158 \mathrm{MPa}$. Stanowi to poważne zagrożenie zniszczenia konstrukcji zaworu, a tym samym utraty podporności przez stojak obudowy.

Na podstawie analizy charakterystyk pracy $p=f(t)$ zaworów bezpieczeństwa, obrazujących zmiany wartości ciśnienia w podtłokowej przestrzeni dwuteleskopowego stojaka hydraulicznego $\phi 320$ podczas obciążania dynamicznego można stwierdzić, że jedynie zawory o konstrukcji suwakowo-tłokowej (z dwoma rzędami otworów wylotowych) oraz gniazdowo-stożkowej, pracowały prawidłowo podczas wszystkich prób i nie wykazywały pulsacji ciśnienia. W przypadku zaworów o konstrukcji suwakowo-tłokowej (z jednym rzędami otworów wylotowych) oraz dwustopniowej, stwierdzono znaczne pulsacje ciśnienia, których skutkiem może być cykliczne przerywanie strugi cieczy w wyniku drgań łłoczka podlegającego z jednej strony naciskowi sprężyny, a z drugiej strony naciskowi wywołanemu ciśnieniem cieczy na wlocie strugi cieczy do zaworu. W przypadku zaworu dwustopniowego, przyczyna pulsacji może być związana $\mathrm{z}$ różnymi stałymi czasowymi dwóch zaworów - sterującego i głównego - umieszczonych w jednej obudowie. Prowadzi to do opóźnienia otwarcia zaworu (Sosnica, 2008), co jest główną przyczyną tego, że zawory dwustopniowe wykazują w badaniach dynamicznych dłuższe czasy otwarcia od zaworów konstrukcji jednostopniowej. Stwierdzone zjawisko powstawania pulsacji ciśnienia może w znacznym stopniu przyczyniać się do obniżenia trwałości stojaka oraz hydraulicznych elementów sterowania sekcji 
obudowy zmechanizowanej, podczas jej pracy w wyrobisku ścianowym, gdzie obciążenie dynamiczne sekcji wynika nie tylko ze wstrząsów górotworu, ale i z technologii wydobycia.

Przeprowadzone badania stojaków hydraulicznych typu SHC obudowy indywidualnej wykazały (Pytlik i Pacześniowski, 2012; Pytlik i Rabsztyn, 2011), że szybkoupustowe baterie zaworowe miały większą skuteczność działania od standardowych baterii montowanych w stojakach SHC, co skutkowało zmniejszeniem ciśnienia w stojaku o $7 \mathrm{MPa}$. Ma to istotne znaczenie dla wytrzymałości cylindra stojaka oraz jego uszczelnień. Badanie stojaka $z$ baterią zaworową polegało na jego dynamicznym obciążeniu poprzez opuszczenie bijaka (masy udarowej) o masie $m_{1}=4000 \mathrm{~kg}$ na stojak rozparty w stanowisku pomiędzy trawersą o masie $m_{2}=3300 \mathrm{~kg}$, a podstawą stanowiska. Rejestrację ciśnienia $\boldsymbol{p}$ cieczy w jego przestrzeni podtłokowej wykonywano z częstotliwością próbkowania 9,6 kHz,

Przeprowadzono również badanie tego samego typu stojaka SHC z baterią typu BZG-2FS (ze sprężyną gazową) przy użyciu masy bijaka $m_{1}=20000 \mathrm{~kg}$ i trawersy o masie $m_{2}=6600 \mathrm{~kg}$. Stojak przeniósł bez zniszczenia obciążenie o charakterze udarowym o wartości energii kinetycznej równej $E_{k}=29,5 \mathrm{~kJ}$. Analiza poklatkowa zdjęć obrazujących moment otwarcia zaworu bezpieczeństwa wykazała, że jego otwarcie nastąpiło po czasie $8 \mathrm{~ms}$ od momentu obciążania stojaka oraz propagację czoła wypływającej strugi cieczy hydraulicznej z prędkością maksymalną ok. $60 \mathrm{~m} / \mathrm{s}$, a maksymalne chwilowe natężenie przepływu cieczy przepływającej przez zawór przelewowy wyniosło $Q_{c \max }=683 \mathrm{l} / \mathrm{min}$.

Podstawowym środkiem zabezpieczającym sekcję obudowy zmechanizowanej podczas zjawisk sejsmicznych, indukowanych działalnością górniczą, jest zawór bezpieczeństwa ograniczający ciśnienie w stojakach i podporach hydraulicznych (Gwiazda, 1997; Jacobi, 1981; Klishin i Tarasik, 2002; Stoiński, 1998;). Głównymi parametrami zaworów bezpieczeństwa są czas jego otwarcia oraz przepustowość, która rozumiana jest jako objętościowe natężenie przepływu (Pospolita, 204) cieczy przepływającej przez zawór.

Do badań charakterystyk pracy zaworów bezpieczeństwa (Pytlik, 2013; Pytlik, 2014), wytypowano zawory z przyłączem gwintowym M40×2 o następujących konstrukcjach:

- suwakowo-tłokowej - z trzema rzędami otworów wylotowych cieczy,

- suwakowo-tłokowej - z dwoma rzędami otworów wylotowych cieczy,

- gniazdowo-stożkowej - z jednym rzędem otworów wylotowych cieczy.

Badania zaworów przeprowadzono na podstawie metodyki badań przepustowości, która polega na impulsowym wzroście ciśnienia strumienia cieczy, wywołanym udarem masy w stojak z zaworem, do wartości 2 krotności ciśnienia roboczego na które nastawiony jest zawór. Taki rodzaj badania symuluje obciążenie dynamiczne stojaka hydraulicznego z zaworem podczas zjawiska tąpnięcia. Wyniki badań przepustowości i czasu otwarcia zaworów mogą być wykorzystane do wyznaczania upodatnienia sekcji obudowy zmechanizowanej oraz do optymalizacji konstrukcji zaworów w celu poprawy przepustowości i szybkości działania.

Na podstawie przeprowadzonych badań chwilowego natężenia przepływu $Q_{c}$ zaworów bezpieczeństwa z przyłączem M40×2 można stwierdzić, że zawory te posiadają dużą przepustowość, którą zobrazowano na wykresach oraz krótki czas działania - od 3 do 5 ms. Najlepszymi parametrami technicznymi wykazał się prototypowy zawór konstrukcji gniazdowo-stożkowej.

Słowa kluczowe: obudowa zmechanizowana; obudowa indywidualna; stojaki hydrauliczne; zawory przelewowe; zawory bezpieczeństwa; przepustowość

\section{Introduction}

Basic safety measure securing the powered roof support during seismic occurrences caused by mining works, is the safety valve limiting the pressure in legs and hydraulic props (Gwiazda, 1997; Jacobi, 1981; Klishin \& Tarasik, 2002; Stoiński, 1998;). Main parameters of safety valves are opening time and capacity which is understood as volume flow intensity (Pospolita, 2004) of a fluid flowing through a valve.

Mining tremors caused by mining works are the main natural threats in Upper Silesian Coal Basin and Legnica-Głogów Copper District (Dubińki \& Mutke, 1996; Mutke et al., 2009). A specific phenomenon of mining tremors is a crump (Dubiński \& Konopko, 2000) which can be defined as: 'a sudden elastic energy discharge in a rock mass, manifesting itself by vibrations 
of rock mass transferring a considerable amount of energy and related to acoustic occurrence and a shock wave. This phenomenon causes destruction of rock structure in a roof, floor or bed with simultaneous dynamic rock relocation that fall into an excavation, and also results in damages or destruction of the roof support or machinery and equipment.

Requirements related to the safety of the powered roof support are defined by standardized Machinery Directive 2006/42/WE (PN-EN 1804-2+A1:2012; PN-EN 1804-3+A1:2012).

It should be noted that the requirements of the current European standard related to legs and hydraulic motor operators (PN-EN 1804-2+A1:2012) replaced requirements and research included in Polish standards (now invalid) PN-G-15530:1996, PN-G-15537:1999 that had defined static and dynamic overload for excavations with frequent tremors, here the value of a safety coefficient amounted to 2.2 times of the working pressure. The standards also specified research methodology of hydraulic legs designed to work in both, safe and hazardous conditions, done by a pile-driver using free fall of $10,000 \mathrm{~kg}$ or $20,000 \mathrm{~kg}$ impact mass.

Resulting legal loophole was supplemented by requirements for a powered roof support defined by Regulation of the Minister of Economy on safety $\S 440$ paragraph. 2 of 2006 (Dz. U. No. 139, item. 1169 of 28.06.2006): 'Powered roof supports designed to work in excavations with tremor hazard should be yielded.' On of the first research and analysis concerning the yielding and estimated leg's load as a result of mining tremors were conducted by Stoiński (1998) at dynamic bench testing post in the Central Mining Institute (GIG). Currently, he method for yielding determination (Stoiński, 2000, 2008; Stoiński \& Pytlik, 2006) applied for powered roof support may include load forecast during a tremor assuming that the hydraulic leg along with the working valve (bypass) and safety valve will transfer the load without causing any damages. The load amounts to at least 1.5 to 2 times of leg's working pressure. Whereas, the requirements imposed by standards considerably narrow the range of tests to 1.2-1.5 times of working pressure, which is, according to the author, insufficient in the case of Polish mining conditions. This is also confirmed by experiments conducted in the mines and gathered in the past few years (Sosnica, 2008; Szurgacz, 2011, 2013). The most recent analysis of damages in a support unit (legs and hydraulic props, working valves and safety valves, and manometers) of powered roof support (Szurgacz, 2013) carried out in several coal mines characterized by the highest level of hazard, has indicated that a number of damages occurred in bypass valves and manometers located in valve banks. These observations suggest that currently the safety level determined according to valid requirements are not sufficient and should be more strickt. This also applies to improvement of present research methodology for bypass and safety valves, in order to indicate better the impact characteristic of leg's load or hydraulic support occurring during the tremor and causing an impulse pressure increase.

The standard (PN-EN 1804-3+A1:2012) related to a hydraulic control system includes a definition of an A type relief valve and therefore, in order to differentiate the valves depending on work specific, it has been suggested to adopt the following Polish terminology of valves (Gwiazda, 1997; Pytlik, 2013):

- bypass valves - mainly designed to maintain stable pressure in a hydraulic system during leg's loads caused by convergence of works' roof.

- safety valves - (also referred to as relief or quick relief) are mainly designed to secure a hydraulic system against loads, this is the reason why the valve is closed during working process and is opened only when the pressure in the system is exceeded by a determined pressure value. This valve should be set at opening pressure of a value higher than pressure adjusted in the bypass valve by at least $15 \%$. 
One of the main parameters of the relief valve is its capacity which is defined as momentary or average intensity of fluid volume stream (Pospolita, 2004) that flows through the valve when pressure reaches certain value.

The developed capacity (flow intensity) research method (Pytlik, 2014) for pressure relief valves defined in the standard (PN-EN 1804-3+A1:2012) as A type (bypass) and safety valves designed to work mainly in hazard conditions of mining tremors, are used to improve safety level of powered roof supports by not allowing the support elements to be damaged. This methodology allows to determine momentary values of volume capacity and the moment of the valve opening thanks to research on a leg equipped with a valve when impulse pressure increase has an impact character. The time when the valve opens decides on the possibility to lower the first pressure peak (having the biggest impact and damaging support elements) caused by a mining tremor.

\section{Test of characteristics of hydralic legs equipped with bypass and safety valves}

\subsection{A test of characteristics of $\phi 320$ double telescopic hydraulic leg equipped with a bypass valve and an additional safety valve}

A double telescopic hydraulic leg $\phi 320$ type equipped with a valve bank with bypass valve and an additional safety valve was subjected to load caused by free flow of impact mass.

The tests included the following safety valves of various design, (Fig. 1 shows a scheme of one of the designs):

- slide-piston with a roll spring impacting the valve's piston, with two rows of outlets, opening pressure of $p_{o}=50 \mathrm{MPa}$ and $\mathrm{M} 40 \times 2$ terminal - no. 1 ,

- seat-cone with a gas spring pressing the cone to the valve's seat, with a single row of outlets, opening pressure of $p_{o}=50 \mathrm{MPa}$ and M $40 \times 2$ terminal - no. 2,

- seat-cone with a gas spring pressing the cone to the valve's seat, with a single row of outlets, opening pressure of $p_{o}=47 \mathrm{MPa}$ and $\mathrm{M} 40 \times 2$ terminal - no. 3,

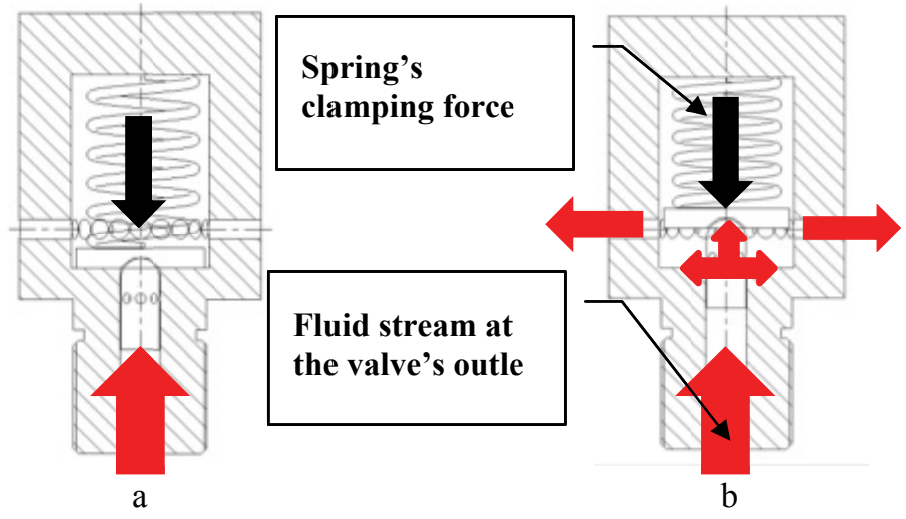

Fig. 1. Construction scheme of the slide-piston safety valve with a single row of outlets: $\mathrm{a}$ - closed valve; $\mathrm{b}$ - open valve 
- slide-piston with a roll spring impacting the valve's piston, with a single row of outlets, opening pressure of $p_{o}=48 \mathrm{MPa}$ and $\mathrm{M} 40 \times 2$ terminal - no. 4,

- slide-piston with a roll spring impacting the valve's piston, with a single row of outlets, opening pressure of $p_{o}=42 \mathrm{MPa}$ and $\mathrm{M} 40 \times 2$ terminal $-\mathbf{n o .} 5$,

- two-stage valve (control and main), with two rows of outlets (one row for the control valve, and the other for the main valve), opening pressure of $p_{o}=47 \mathrm{MPa}$ and M $45 \times 2$ terminal - no. 6.

The tests conducted on the legs were carried out at pile testing bench in the Central Mining Institute in Łaziska Górne (Fig. 2). The tests included dynamic loading of the hydraulic leg (equipped with the valve bank with the bypass valve and a terminal for an additional safety valve) by free fall impact mass of $m_{1}=20,000 \mathrm{~kg}$ ram from various $h$ heights and released on $m_{2}=6600 \mathrm{~kg}$ cross-bar which statistically loads the leg. The leg was placed between blocking bolts and the foundation of the bench.

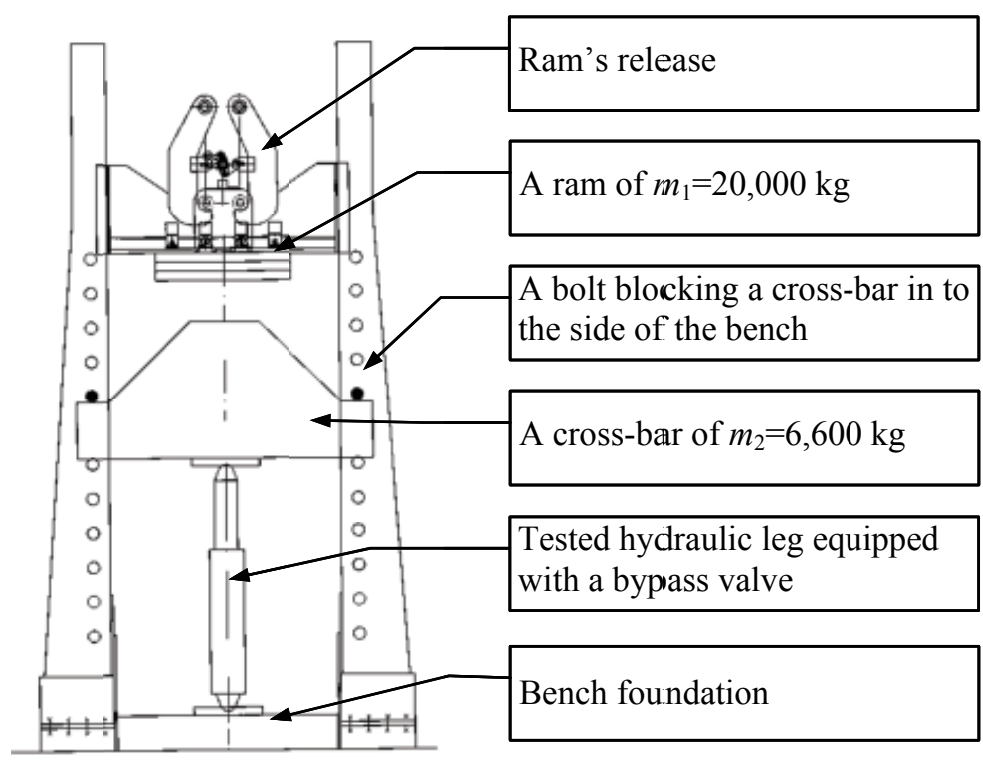

Fig. 2. Scheme of a pile testing bench

$v_{\mathrm{o}}$ velocity of the ram freely falling from $h$ height on a cross-bar in the time of the impact is calculated by the formula:

$$
v_{o}=\sqrt{2 g h}
$$

where:

$g$ - gravitational acceleration.

$v_{u}$ - velocity of $m_{1}$ and $m_{2}$, is calculated applying the Momentum principle: 


$$
m_{1} \cdot v_{o}=\left(m_{1}+m_{2}\right) v_{u}
$$

therefore:

$$
v_{u}=v_{o} \frac{m_{1}}{m_{1}+m_{2}}
$$

$v_{u}$ velocity is adopted as an initial velocity of leg's load, therefore, it is applied to the formula of kinetic energy of connected masses $m_{1}$ and $m_{2}$ :

$$
E_{k}=\frac{1}{2}\left(m_{1}+m_{2}\right) v_{u}^{2}
$$

Finally, after substituting the formula (4) by (1) and (3) the amount comes to:

$$
E_{k}=\frac{m_{1}^{2}}{\left(m_{1}+m_{2}\right)} g \cdot h
$$

where:

$$
\begin{aligned}
m_{1} & - \text { impact mass, } \mathrm{kg}, \\
m_{2} & - \text { cross-bas mass, } \mathrm{kg}, \\
h & - \text { ram's mass release height, } \mathrm{m}, \\
g & - \text { gravitational acceleration, } \mathrm{m} / \mathrm{s}^{2} .
\end{aligned}
$$

The momentum of connected masses $m_{1}$ and $m_{2}$ that load the leg at the time of the impact amounts to:

$$
P=\left(m_{1}+m_{2}\right) \cdot v_{u}
$$

The value of momentum is well characterised by a research on impact, which was confirmed by experimental tests (Gumuła, 2005) conducted in order to define a new design solution (a device - a storage-convert converter - so-called EPAR) of powered roof supports resistant to mining tremors.

Pressure measurements in time function were registered by a sensor connected with the space under the piston by a terminal with $\mathrm{M} 40 \times 2$ thread, which allows to connect tested valve and pressure sensor to a seat chosen by a manufacture to be connected with the safety valve.

Measurement system produced by HBM company was composed of a strain gauge sensor ( 0.2 class) and a measuring amplifier ( 0.03 class) with frequency range up to $10 \mathrm{kHz}$ and optional signal filtration done by low pass Bessel's filters characterised by a minimum amplitude and signal phase deformation.

A computer connected with the measuring amplifier by GPIB or USB; accelerated port was used to register the measurements. All dynamic measurements were taken with minimum sampling frequency $-9.6 \mathrm{kHz}$.

The tests were conducted with high $h$ heights of ram's release $-0.2 \mathrm{~m}$ up to $0.5 \mathrm{~m}$.

Pressure pulsation at release from $h=0.2 \mathrm{~m}$ (reaching about $70 \mathrm{MPa}$ ) were registered during the tests of the leg equipped with two-stage valve no. 6 . Significant pressure pulsation was noted also in the case of valve no. 5 at $h=0.25 \mathrm{~m}$ (reaching about $75 \mathrm{MPa}$ ) and valve no. 4 at $h=0.3 \mathrm{~m}$ (Fig. 3). Pressure charts illustrate how fast the amplitudes of pressure increase with the height of the ram increase, thereby, kinetic energy of ram's stroke impacting the leg equipped with the valve. 
Maximum pressure in the leg with valve no. 5 raised from $64 \mathrm{MPa}$ at $h=0.25$ up to $129 \mathrm{MPa}$ at $h=0.3 \mathrm{~m}$ i.e. by $100 \%$. Due to possible leg damages, the tests on valves no. 5 and 6 were continued at release height of $h=0.5 \mathrm{~m}$. Leg tests with valve no. 4 resulted in pressure increase to $\boldsymbol{p}_{\max }=158 \mathrm{MPa}$, as shown in Fig. 3 in the form of a diagram $p=f(t)$ marked with a red colour.

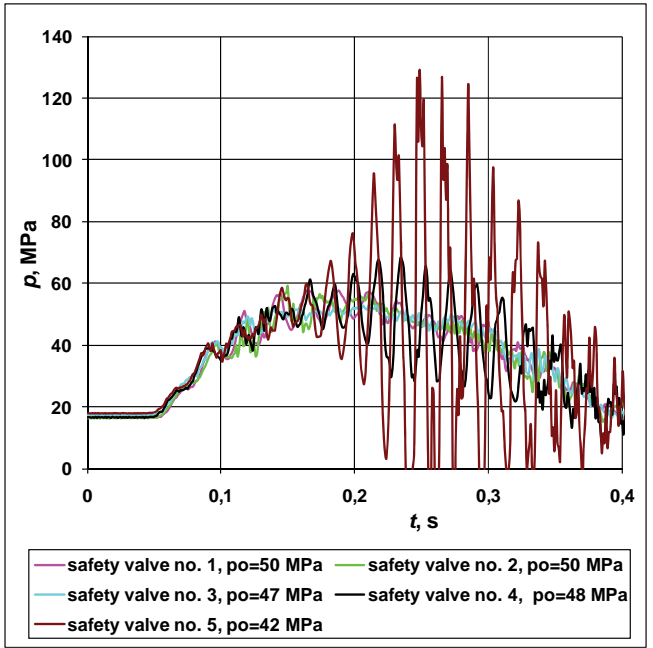

$h=0.3 \mathrm{~m} ; E_{k}=44.3 \mathrm{~kJ}, P=48522 \mathrm{~kg} \cdot \mathrm{m} / \mathrm{s}$

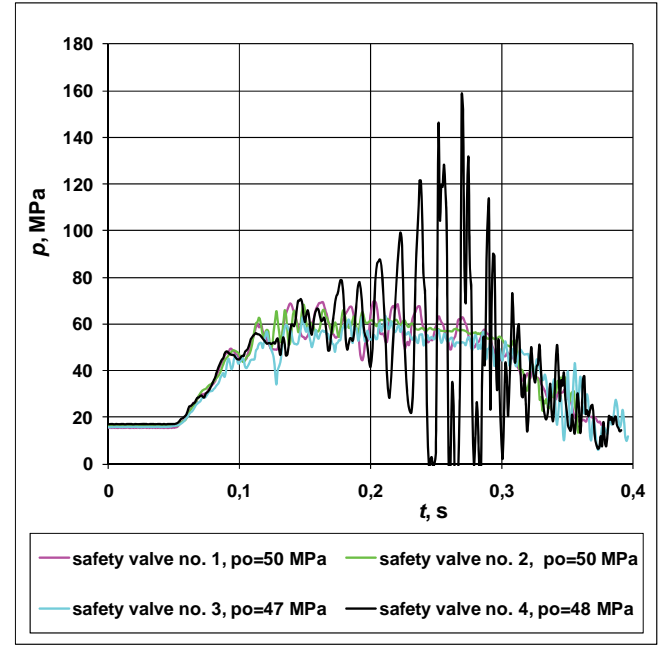

$h=0.5 \mathrm{~m} ; E_{k}=73.8 \mathrm{~kJ}, P=62642 \mathrm{~kg} \cdot \mathrm{m} / \mathrm{s}$

Fig. 3. Process characteristics of safety valves - diagram of pressure drop and increase in $p=f(t)$ time function: $\mathrm{a}-$ at $h=0.3 \mathrm{~m}, \mathrm{~b}-$ at $h=0.5 \mathrm{~m}$

Despite the fact, that the pressure value exceeded the working pressure value of the leg (47 MPa) by $\mathbf{2 3 6 \%}$, the leg and the valve were not subject to any damage due to short working time of particular pressure peaks and a single test. At in situ conditions the legs are subject to repeated dynamic loads. The pressure drop and increase was registered during the test of valves no. 1, 2 and 3. They did not indicate any tendencies to cause pressure pulsation at the height of impact mass release between $0.2 \mathrm{~m}$ up to $0.5 \mathrm{~m}$.

Based on an analysis of work characteristics of $p=f(t)$ safety valves that illustrate the changes in pressure in the space under the piston of a double telescopic hydraulic leg $\phi 320$ type during dynamic load, it can be assumed that only valves no. 1, 2 and 3 worked properly during all tests and did not indicate pressure pulsation. In the case of valves no. 4 and 5 the pressure pulsation may result in repeated broken fluid streams as a result of plunger's vibrations that is impacted by spring's pressure and pressure caused by fluid's pressure at the inlet of the fluid's stream to the valve. The reason of pulsation in the two-stage valve with M $45 \times 2$ thread may by connected to different time constants of two valves - control and main - located in the same roof support. This leads to delayed opening of the valve (Sosnica, 2008) which is the main reason of the fact that during dynamic tests opening times of two-stage valves are longer than in the case of onestage valves. Pressure pulsation of a value significantly exceeding allowable pressure of the leg was registered during the operation of valves no. 4,5 and 6., i.e. $47 \times 1.5 \mathrm{MPa} 70.5 \mathrm{MPa}$. Stated occurrence of pressure pulsation may considerably contribute to lower stability of the leg and 
hydraulic elements of powered roof support control during support's work in the mining works where the dynamic load results not only from mining tremors, but also from the technology of mining. In the case of mining using caving method, the support can be subject to repeated collapsing of roof's layers with lower load value than during a mining tremors. It may lead to damages of a hydraulic support and control elements as a result of material fatigue.

Damages of powered roof support's elements resulting from mining tremors are described in details in the doctoral thesis by Szurgacz (2013). The occurrences are defined on the basis of rockubrst that had taken place in the mines of Upper Silesian Coal Basin: KWK RydułtowyAnna, KWK Katowice, KWK Wujek Ruch Śląsk, KWK Bielszowice, KWK Bobrek-Centrum. Moreover, they confirm the direct influence of an excessive increase of pressure in damaged legs caused by insufficient capacity of safety system against overloads, often faulty connections of a valve bank and faulty connections of a relief valve terminal in the space under the piston.

\subsection{Tests of features of $\phi 120 \mathrm{SHC}$ hydraulic leg equipped with a valve battery}

Other element widely used in the mining industry is a SHC hydraulic leg of an individual roof support used as an support element of the roof with static and dynamic load occurring during mining tremors and rock burst. Currently, additional bypass valves (e.g. mounted at the bottom of a piston) or quick relief valve batteries (Pytlik \& Rabsztyn, 2011, Pytlik et al., 2012) are mounted in SHC legs in the place of traditional valve batteries. The batteries work faster and have higher level of capacity. They are implemented in order to increase leg's dynamic resistance. Quick relief valve batteries may simultaneously be used as a bypass valve and a safety valve.

Tests on SHC leg equipped with BZG-2FS valve battery, seat-cone design with pressing gas spring, at dynamic load, were conduced at the test bench presented in Fig. 2. The design of the valve battery is protected by patents registered at Polish Patent Office, no. P.388584, titled: 'Valve battery for the hydraulic prop' and P.387582 titled: 'Gas spring'.

The test of the leg with a valve battery was based on its dynamic load impacted by a ram (impact mass) of $m_{1}=4,000 \mathrm{~kg}$ relieved at the leg placed between a cross-bar of $m_{2}=3,300 \mathrm{~kg}$ and post's foundation. Recording of the $\boldsymbol{p}$ pressure of the fluid in its space under piston was taken with sampling frequency of $9.6 \mathrm{kHz}$, according to the mentioned measuring device. Comparison of a standard and quick relief valve battery BZG-2FS type is presented in Figure 4.

Conducted tests showed that quick relief valves had higher efficiency than standard valves mounted in SHC legs, what resulted in lower pressure in the leg by $7 \mathrm{MPa}$. It has an essential importance for stability of leg's cylinder and its sealing.

Moreover, the research also included the test of the same type of SHC leg with BZG-2FS battery using ram's mass of $m_{1}=20,000 \mathrm{~kg}$ and the cross-bass of $m_{2}=6,600 \mathrm{~kg}$. 1).

The leg transferred the load, stroke type, of $E_{k}=29,5 \mathrm{~kJ}$ kinetic energy without any damages. Photo 1 shows a hydraulic fluid stream flowing with maximum velocity of about $60 \mathrm{~m} / \mathrm{s}$. The fluid flows out of BZG-2FS quick relief valve mounted in SHC hydraulic leg (Pytlik et al., 2012). A time-lapse analysis of photos showing the opening moment of the safety valve indicated that its opening took place $8 \mathrm{~ms}$ after the moment when the leg had been impacted and indicated propagation of the hydraulic fluid stream's front with maximum velocity of about $60 \mathrm{~m} / \mathrm{s}$, and maximum momentary intensity of fluid flowing through a bypass valve amounted to $Q_{c \max }=683 \mathrm{l} / \mathrm{min}$. SHC leg with BZG-2FS battery, which was damages during the test at $\boldsymbol{h}=0,3 \mathrm{~m}$ is resented in photo $1 \mathrm{~b}$. 


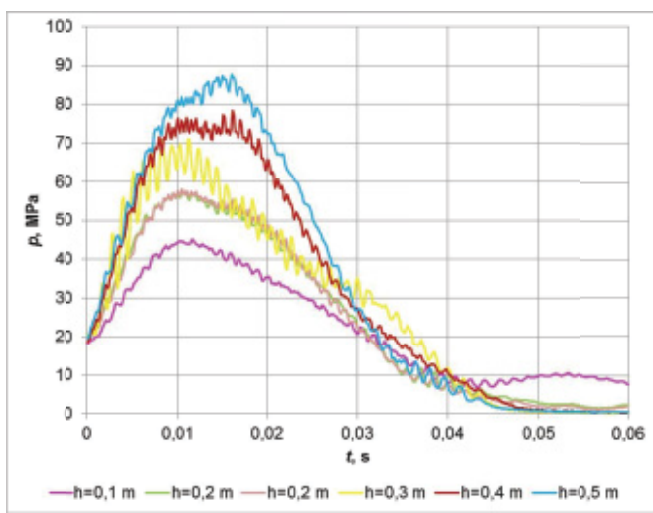

a

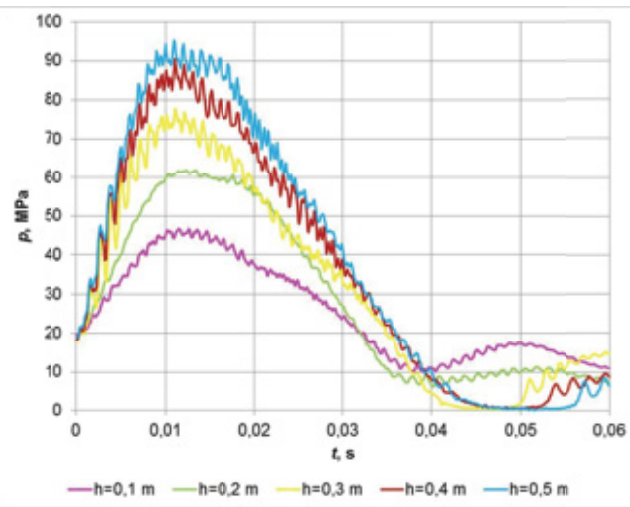

b

$h=0.5 \mathrm{~m} ; E_{k}=10.8 \mathrm{~kJ}, P=12528 \mathrm{~kg} \cdot \mathrm{m} / \mathrm{s}$

Fig. 4 Comparison of working process $\boldsymbol{p}=f(\boldsymbol{t})$ : a - a quick relief valve BZG-2FS, b - a standard battery

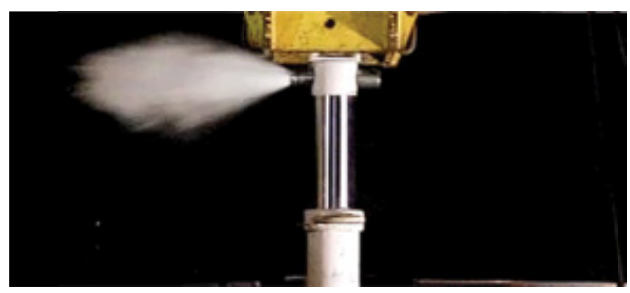

a

$E_{k}=29.5 \mathrm{~kJ}, P=39618 \mathrm{~kg} \cdot \mathrm{m} / \mathrm{s}$

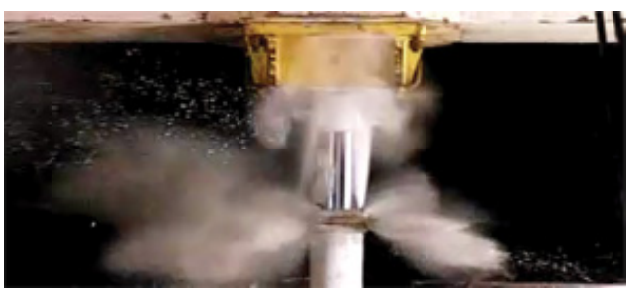

$\mathrm{b}$

$E_{k}=44.3 \mathrm{~kJ} ; P=48522 \mathrm{~kg} \cdot \mathrm{m} / \mathrm{s}$

Photo. 1. SHC leg tests: a - the leg was not damaged, b - the leg was damaged (torn off sealing of a leg's stuffing-box, deformed cylinder and buckling of the leg)

\subsection{Tests of features of working process and opening times of bypass and safety valves at impulsive pressure increase}

Long-standing experience of Polish and foreign researchers (Krumnacker \& Kleefeld, 1985; Olaszowski et al., 1976) in the field of powered roof supports working in hazard conditions of mining tremors show that the maximum displacement of the roof as a result of dynamic impact of the rockmass may reach $550 \mathrm{~mm}$, and sliding velocity reaches $-\mathbf{2} \mathbf{~ m} / \mathbf{s}$. The above data was acquired form individual measurements taken in Czech Republic, RPA and estimations based on the experience gained by German mines. According to research conducted by Szweda (2004) an estimated value of rock block mass (during sudden slide of a lump) is lower than $40,000 \mathrm{~kg}$, the time value of dynamic load increase of the roof support from the side of the floor reaches about $7 \mathrm{~ms}$ and $k_{d}$ coefficient (relation of the biggest support's load to its static load) of dynamic load may reach 1,8 (Szweda, 2001).

One of the few cases of dynamic load in the roof support, caused by a natural crump (not provoked by explosives) werre registered by prof. Yuri G. Shein (2002). The results of the crump 
were registered in two adapted powered roof support units with two legs (chock support) working in the mines of Baltic Basin. A coal bed of $1.8 \div 1.9 \mathrm{~m}$ thickness lied at $\mathbf{7 5} \mathbf{~ m}$ depth. Two sections of the powered roof support were equipped with pressure (working frequency of $1,000 \mathrm{~Hz}$ ) and displacement sensors. The maximum registered velocity of subsiding of roof support during a crump reached $65 \mathrm{~mm} / \mathrm{s}$; and at time range $\mathbf{0 . 1} \mathrm{s}$, at the maximum load intensity, registered pressure increase velocity reached $50 \mathrm{MPa} / \mathrm{s}$. Measured hydraulic leg's overload exceeded $\mathbf{1 . 3} \div \mathbf{1 . 5}$ times of its working load-bearing capacity.

Such phenomena occurring in valves were described other by researchers a long time ago (Guillon, 1967), however, in the case of great velocities of fluid streams, they are difficult to define using a mathematical description. Because of that, the research team decided to design an experimental methodology for determination of fluid flow intensity which often exceeds $100 \mathrm{MPa}$.

Bench testing assumed impact mass system available in the Laboratory; concise value of $23,300 \mathrm{~kg}$. The assumption is in accordance with parameters included in references (Szweda, 2004) which relate to sudden lump slide during which the mass of rock lump impacting the leg is smaller than $40,000 \mathrm{~kg}$. Valve tests were carried out at a test bench. Its scheme is presented in Fig. 5.

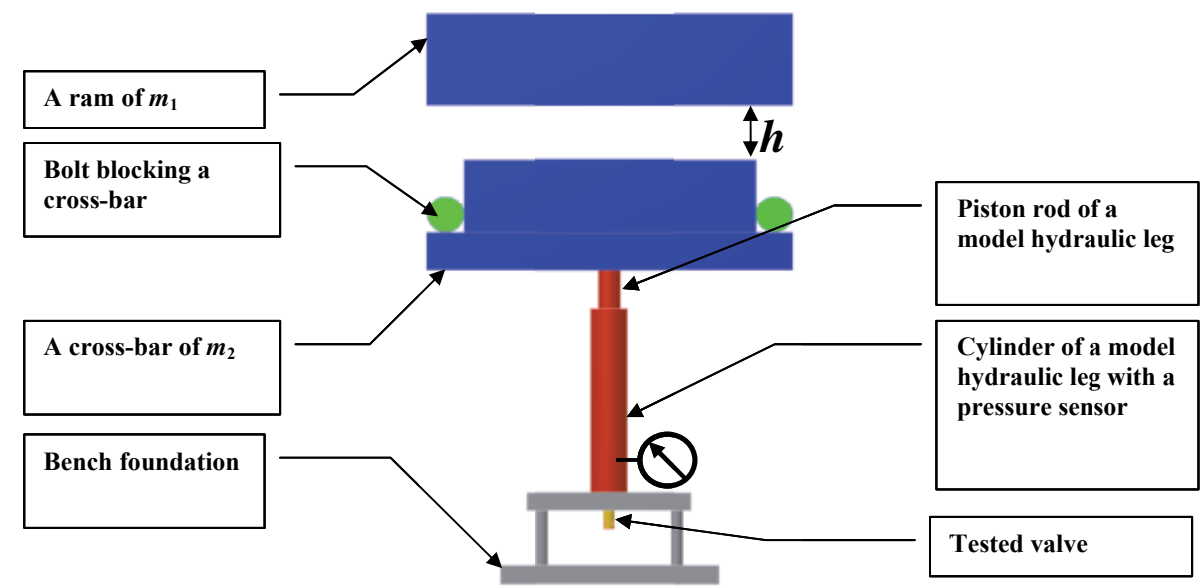

Fig. 5. Valve test bench

The tests of valves according to a method are based on:

- determination of opening and closing pressure of the valve acc. to A.1.3.3. of the standard (PN-EN 1804-3+A1:2012).

- dilation of the hydraulic leg with $\boldsymbol{D}=\mathbf{1 2 0} \mathbf{~ m m}$ inner diameter of the cylinder, to the side of the bench up to pressure of $60 \%$ of $\boldsymbol{p}_{\boldsymbol{r}}$ working pressure - pressure value set in the leg.

- loading the leg equipped with tested valve and gradual increase of $\boldsymbol{h}$ height of the ram $\left(\boldsymbol{m}_{\mathbf{1}}=20,000 \mathrm{~kg}\right)$ released on the cross-bar $\boldsymbol{m}_{\mathbf{2}}=3,300 \mathrm{~kg}$, statistically loading the model hydraulic leg) so it reaches the maximum $\boldsymbol{p}_{\text {cmax }}$ pressure of hydraulic fluid in the space of the model leg equipped with the tested valve to about twice the $2 \times \boldsymbol{p}_{\boldsymbol{r}}$.

- checking the leg's sealing after the test by another leg's dilation laced in the frame of the bench with pressure of about $60 \%$ of $\boldsymbol{p}_{\boldsymbol{r}}$. working pressure

- the test result are positive if the valve after the tests is not damaged and is still tight. 
The tests are followed by calculations of momentary $Q_{c}$ flow intensity for each height of ram's release and a maximum value of momentary $Q_{c \max }$ flow intensity for every trial. Then, process characteristics are determined in the form of $p_{c \max }=f\left(Q_{c \max }\right)$ relation. $\boldsymbol{v}_{\boldsymbol{u}}$ stroke velocity impacting the model leg equipped with testes valve is dependent on $\boldsymbol{h}$ height. During free fall test, value $\boldsymbol{h}$ should be gradually increased, to the point it reaches about $1.5 \div 2$ times of $\boldsymbol{p}_{\boldsymbol{r}}$ working pressure set in the valve. Pressure $\boldsymbol{p}$ measurement is conducted by a strain gauge sensor, whereas the measurement of slide $\mathbf{z}$ from a hydraulic piston rod is carried out by a dislocation sensor. Measurement data from the sensors are registered with measuring frequency of 9,600 Hz, and the scheme of selected tests is registered by quick CASIO camera with 1,200 frames/s, which allows to determine the opening time of the valve and to determine typical points on the pressure chart and a slide in the time function.

Momentary $Q_{c}$, volume of stream value is defined as momentary volume value of flow intensity and is calculated by the formula:

$$
Q_{c}=\lim _{\Delta t \rightarrow 0} \frac{\Delta V}{\Delta t}, \mathrm{dm}^{3} / \min
$$

where:

$\Delta V-$ increment of fluid flowing through the valve, $\mathrm{dm}^{3}$,

$\Delta t$ - time increment, $\mathrm{s}$.

Volume increment $\Delta V$ is calculated by the formula:

$$
\Delta V=S \cdot \Delta z, \mathrm{dm}^{3}
$$

where:

$\Delta z$ - increment of a hydraulic piston rod's slide, $\mathrm{dm}$,

$S$ - surface of a hydraulic piston calculated by the formula:

$$
S=\frac{\pi \cdot D^{2}}{4}, \mathrm{dm}^{2}
$$

where: $D=120 \mathrm{~mm}$ — diameter of model leg's cylinder equipped with the tested valve.

Registered flows of $\boldsymbol{p}$ pressure and volume intensity of $\boldsymbol{Q}_{\boldsymbol{c}}$ flow in time function, showing pressure pulsation and flow intensity of dampened fading vibrations, give the maximum $\boldsymbol{p}_{\boldsymbol{c} \text { max }}$ and $\boldsymbol{Q}_{\boldsymbol{c m a x}}$, peaks intensity and their outlines are determined on their basis.

The test results provided the characteristics of momentary maximum pressure $p_{c \max }$ in momentary volume function of flow intensity $Q_{c \max }$ when the valve is working.

Three types of valves were included in the tests. The valves were equipped with M $40 \times 2$ thread terminal set at opening pressure of $p_{r}=43 \mathrm{MPa}$. The following valves were tested:

- slide-piston (inlet diameter $\phi 16 \mathrm{~mm}$ ) with cut main body of the valve's piston, having three rows of drilled outlets in the from of a rim; fluid flows out of the valve through the outlets (Fig. 6),

- slide-piston (inlet diameter $\phi 14 \mathrm{~mm}$ ) with cut main body of the valve's piston, having two rows of drilled outlets in the form of a rim,

- seat-cone (inlet diameter $\phi 15 \mathrm{~mm}$ ) having a single row of drilled outlets in the from of a rim (Fig. 6b). 


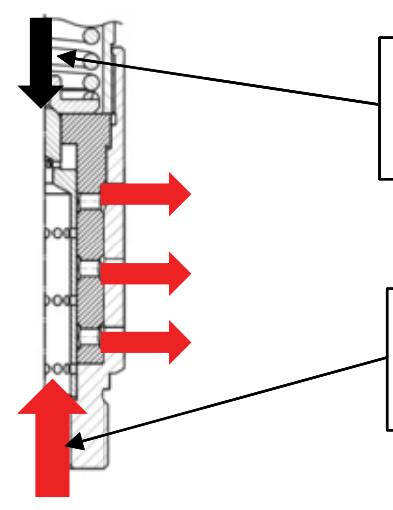

a

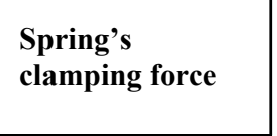

Fluid stream at
the valve's outlet

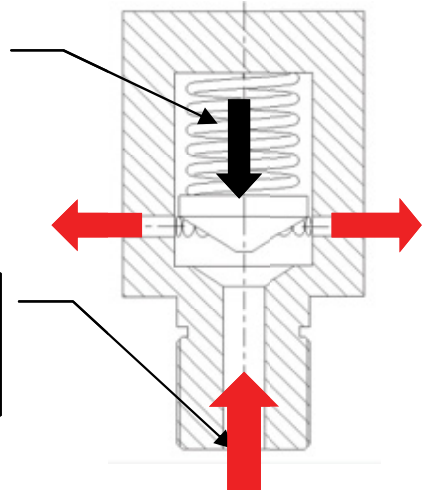

b

Fig. 6. Construction scheme of safety valves: $\mathrm{a}$ - slide-piston design, $\mathrm{b}$ - seat-cone design

\subsubsection{Tests of features of the slide-piston valve with two rows of outlets}

Figure 7 shows sample charts of $p$ pressure relation in the space under the piston, $\mathbf{z}$ slide of an upper prop and momentary $\boldsymbol{Q}_{\boldsymbol{c}}$ flow intensity in the $t$ time function registered during a test at ram's release height at $h=0,4 \mathrm{~m}$.

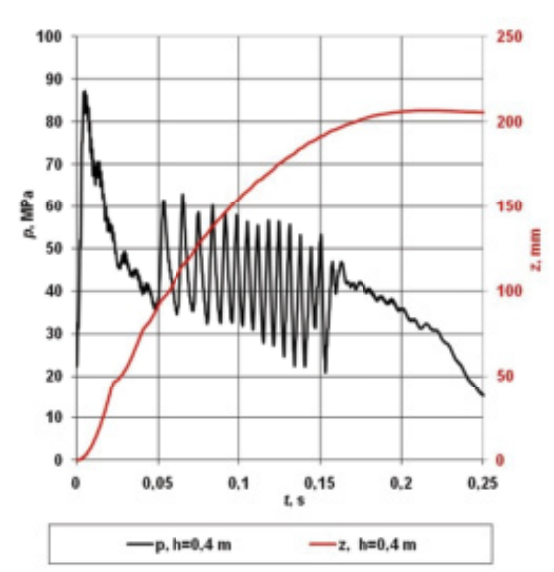

$\mathrm{a}$

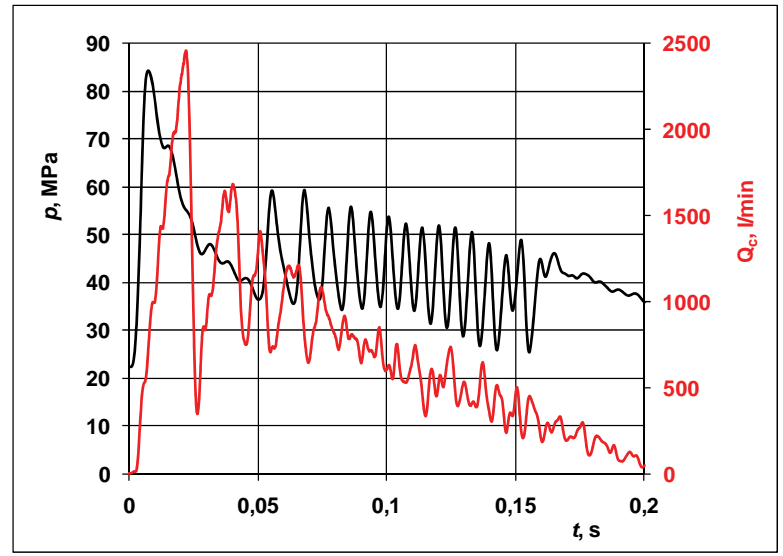

b

Fig. 7. Chart of $\boldsymbol{p}$ pressure relation in the space under the piston, $\mathbf{z}$ slide of an upper prop and momentary $\boldsymbol{Q}_{\boldsymbol{c}}$ flow intensity in the $t$ time function registered during a test at ram's release height at $h=0,4 \mathrm{~m}$

A spectrum density analysis of pressure and slide power signal may serve as a basis of filtration of both signal by digital implementation of Bessel's filter.

Filtered $z=f(t)$ slide signal would then be differentiated which could allow to calculate the momentary velocity of piston's slide. Next, the velocity could be used to determine the volume 
value of $\boldsymbol{Q}_{\boldsymbol{c}}$ flow intensity. Registered flows of $\boldsymbol{p}$ pressure and volume intensity of $\boldsymbol{Q}_{\boldsymbol{c}}$ flow in $t$ time function, showing pressure pulsation and flow intensity of dampened fading vibrations, give the maximum $\boldsymbol{p}_{\boldsymbol{c}}$ and $\boldsymbol{Q}_{\boldsymbol{c}}$. Their sample outlines presented in Fig. 8a, form a logarithmic and exponential line. Such outlines show dampening of the valve. Sample characteristics of the valve in the form of relations of $p_{c \max }$ maximum pressure in the function of $Q_{c \text { max }}$ maximum momentary flow intensity are presented in Fig. $8 \mathrm{~b}$.

Photo 2 shows a sequence of time-lapse photos registered during a valve test. The photos illustrate subsequent phases of valve's opening and closing. Time-lapse analysis shows that the opening time of the valve lasts for about $4 \mathbf{~ m s}$.

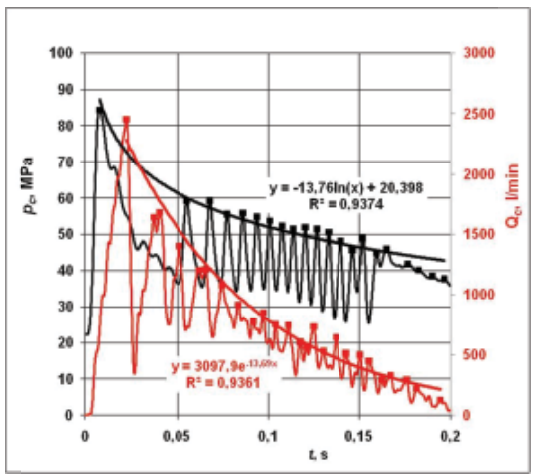

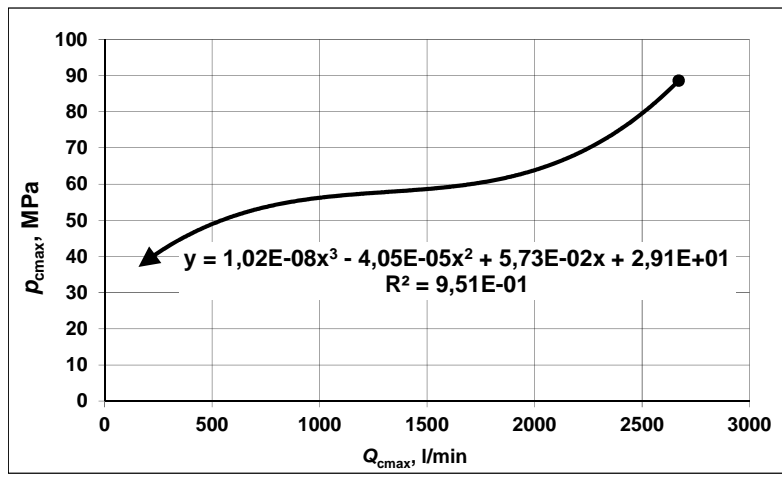

b

Fig. 8. Process characteristics: $\mathrm{a}-$ outlines of pressure and momentary flow intensity, $\mathrm{b}-p_{c \max }$ maximum pressure in the function of $Q_{c \max }$ maximum momentary flow intensity

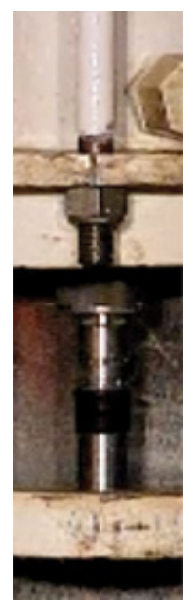

a

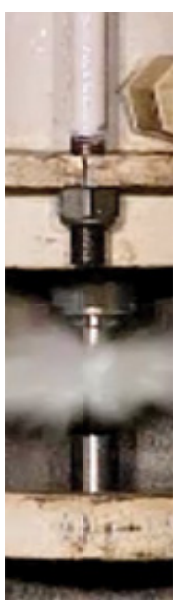

b

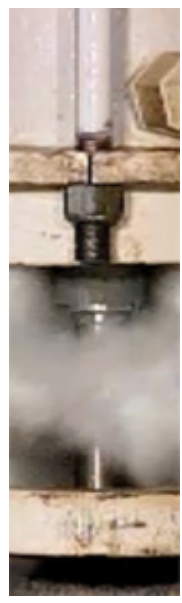

$\mathrm{C}$

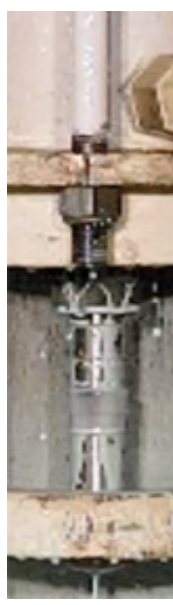

d

Photo. 2. Subsequent stages of valve's working process: a - closed valve before the test; $\mathrm{b}$ - valve in the initial opening phase; $\mathrm{c}$ - valve fully opened; $\mathrm{d}$ - closed valve after the test 


\subsubsection{Tests of features of the slide-piston valve with three rows of outlets}

Figure 9a shows sample charts of $\boldsymbol{p}$ pressure relation and momentary $\boldsymbol{Q}_{c}$ flow intensity in the $t$ time function. Figure $9 \mathrm{~b}$ presents relations of $p_{c \max }$ maximum pressure in the function of $Q_{c \max }$ maximum momentary flow intensity registered during a test at ram's release height at $h=0,25 \mathrm{~m}$.

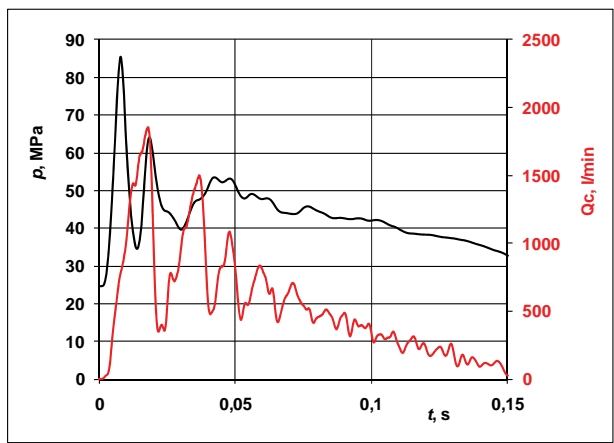

a

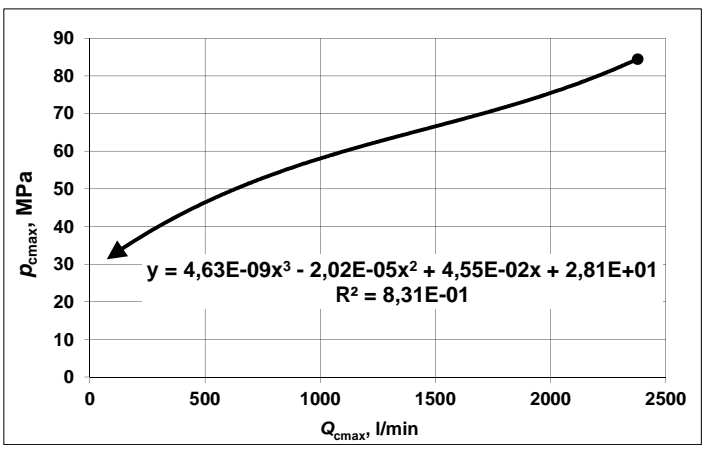

$\mathrm{b}$

Fig. 9. Relation scheme: $\mathbf{a}-\boldsymbol{p}$ pressure in the space under the piston and momentary $\boldsymbol{Q}_{\boldsymbol{c}}$ flow intensity in the $t$ time function, $\mathrm{b}-p_{c \max }$ maximum pressure in the function of $Q_{c \max }$ maximum momentary flow intensity

An analysis of valve features at the time of ram's impact to the leg at release height of $h=0.25 \mathrm{~m}$ shows that the opening time of the valve lasts about $5 \mathrm{~ms}$. Longer opening time may be caused by greater resistance that the lunger must go through in the main body. The resistance is the result of the number of outline sealing of the plunger and by another characteristic of the spring used in the valve (greater force is necessary in order to maintain the plunger in stable position in the case of the valve with two rows of outlets).

\subsubsection{Test results of a seat valve with a single row of outlets}

Figure 10 shows sample charts of $p$ pressure relation in the space under the piston in the $t$ time function registered during a test at ram's release height at $h=0,5 \mathrm{~m}$.

Work character of the valve (cone pressing it to the seat by a set of plate springs) indicated that it has very good properties of impact energy dampness without the lowering the load-bearing capacity level of a hydraulic leg. No rapid pressure drop occurs in the space under the piston in contrary to earlier tested slide-piston valves. In practice it is significant for maintenance of high load-bearing capacity level of the leg. Rock mass sliding down to the mining works during a tremor can be slowed down thanks to this characteristic. Photo 3 shows a sequence of time-lapse photos registered during a valve test. The photos illustrate subsequent phases of valve's working process.

Opening time of the valve lasts about 3 ms. Short opening time is influenced by minor friction in the system which occurs during the opening. The shape of fluid stream during valve's opening is different in comparison to slide-piston valves. The stream has greater surface and is directed through the valve's cone. Moreover, the valve is characterized by lower resistance of the cone due to smaller number of seals. 


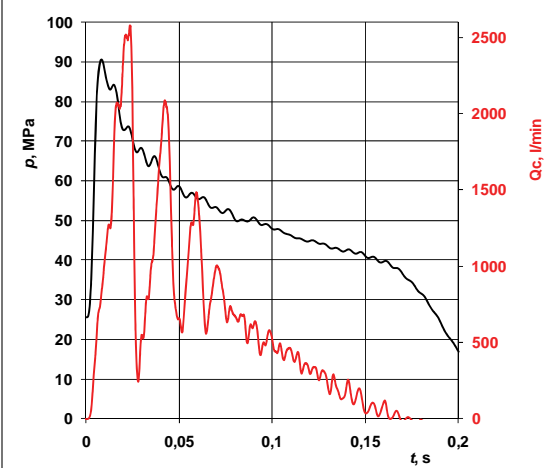

a

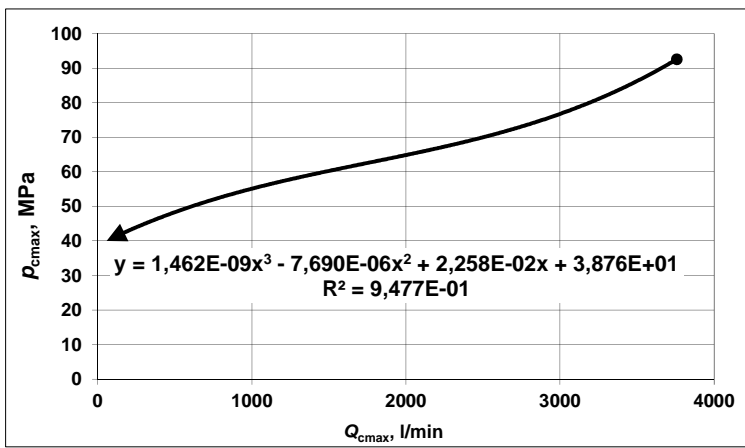

b

Fig. 10. Relation scheme: $\mathbf{a}-\boldsymbol{p}$ pressure in the space under the piston and momentary $\boldsymbol{Q}_{\boldsymbol{c}}$ flow intensity in the $t$ time function, $\mathrm{b}-p_{c \max }$ maximum pressure in the function of $Q_{c \max }$ maximum momentary flow intensity

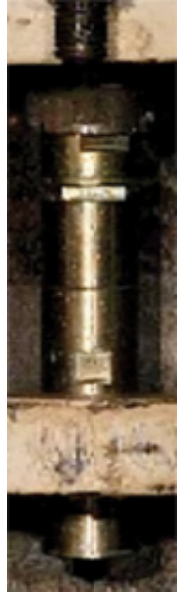

a

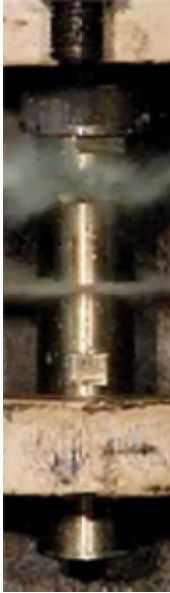

b

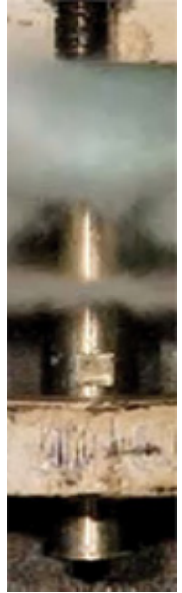

c

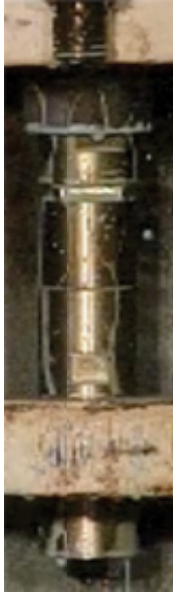

d

Photo. 3. Subsequent stages of valve's working process: $a$ - closed valve before the test; $b$ - valve in the initial opening phase; $\mathrm{c}$ - valve fully opened; $\mathrm{d}$ - closed valve after the test

\section{Conclusion}

Tests on valves at dynamic load showed that safety valves may efficiently protect their construction if the opening times are short (a few $\mathrm{ms}$ ) and have relatively high capacity values (volume flow intensity) that are determined during roof support's yielding process. Fluid pulsation caused by faulty valve is unacceptable.

On the basis of carried out research concerning momentary intensity of $Q_{c}$ flow of safety valves with $M 40 \times 2$ terminal, it may be stated that the valves are characterised by a high level 
of capacity, presented on charts, and short working time. The best technical parameters had a prototype seat-cone valve.

Developed methodology may be used to determine flow intensity when the pressure increase has an impulsive character. Moreover, it can be applied while comparing different designs of pressure relief valves and their terminals, which decide on the capacity level of the valve to a great extent. The research method completes the standard and simulates the work of a valve during a tremor, therefore, it is especially recommended as a method applied during the yielding of a powered roof support's section.

Bypass and safety valves tests shall be continued in order to search for new valve's designs that will shorten opening times and optimize existing designs to hazardous conditions of mining tremors.

\section{References}

Dubiński J., Konopko W., 2000. Tapania: ocena, prognoza, zwalczanie [Tremors: evaluation, forecast, elimination]. The Central Mining Institute. Katowice

Dubiński J., Mutke G., 1996. Characteristics of mining tremors within the near-wave field zone. PAGEOPH., Vol. 147, No. 2, s. 249-261. DOI: 10.1007/BF00877481

Guillon M., 1967. Teoria i obliczanie układów hydraulicznych [The theorr and calculations of hydraulic units]. Wydawnictwo Naukowo-Techniczne, Warszawa.

Gumuła S., 2005. A new concept of hydraulic mechanized supports resistant to the crumps. Archives of Mining Sciences, 50,3 (2005), 275-288.

Gwiazda J.B., 1997. Górnicza obudowa hydrauliczna odporna na tapania [Tremor resistant mining roof support]. Katowice. Wydaw. „Śląsk”.

Irresberger H., Gräwe F., Migenda P., 2008. Obudowy zmechanizowane. [Powered Roof Supports]. Katowice. Tiefenbach Polska Sp. z o.o., 2008.

Jacobi O., 1981. Praxis der Gebirgsbeherrschung 2. Auflage. Essen. Verlag Glückauf GmbH.

Klishin V.I., Tarasik T.M., 2002. Badania doświadczalne i opracowanie środków ochrony stojaków hydraulicznych przed obciażeniami dynamicznymi [Experimental research and design of measurement protecting hydraulic legs against dynamic loads]. International Symposium on Science and Technology, Tremors, 2002. Research and Prevention Condition. The Central Mining Institute. Katowice, 127-138.

Krumnacker I., Kleefeld R., 1985. Bemessungsgrundlagen für hydraulische Grubenstempel unter Belastung von Gebirgsschlägen. Glückauf - Forschungshefte nr 5, p. 237-244.

Mutke G., Lurka A., Dubiński J., 2009: Seismic monitoring and rock burst hazard assessment in Deep Polish Coal Mines - Case study of rock burst on April 16, 2008 in Wujek-Slask Coal Mine. 7th International Symposium on Rockburst and Seismicity in Mines (RASiM 7): Controlling Seismic Hazard and Sustainable Development of Deep Mines. C.A. Tang (ed.). Rinton Press. pp. 1413-1424.

PN-EN 1804-2+A1 Standard: 2012 - Machines for underground mining - Safety requirements for powered roof supports - Part 2: Power set legs and rams.

PN-EN 1804-3+A1 Standard: 2012 - Machines for underground mining - Safety requirements for powered roof supports - Part 3: Electrohydraulic control.

Olaszowski W., Kornecka A., Podgórski B., Hanaś A., 1976. Wstępne rozpoznanie parametrów tapań stropowych $i$ warunków wspótpracy obudowy z górotworem [Preliminary identification of parameters of roof crumps and conditions for cooperation of a roof support and rockmass]. Mechanizacja i Automatyzacja Górnictwa, 12, 48-56.

Pospolita J., 2004. Pomiary strumieni plynów [Fluid flow measurements]. Opole University of Technology. Studia i monografie, z. 154, Opole. 
Pytlik A.,, 2013. Stanowiskowe badania przepustowości zaworów bezpieczeństwa stojaków obudowy zmechanizowanej przy impulsowym wzroście ciśnienia symulujacym tapnięcie [Bench testing of capacity level of safety valves in powered roof support at impulsive increase of pressure simulating a tremor]. Przegląd Górniczy, 07 (1088), June 2013, Katowice, 28-34.

Pytlik A., 2014. Badania porównawcze przepustowości zaworów bezpieczeństwa stojaków obudowy zmechanizowanej przy impulsowym wzroście ciśnienia symulującym tapnięcie [Comparison tests of capacity level of safety valves in powered roof support at impulsive increase of pressure simulating a tremor]. Report of works conducted within statutory practice of the Central Mining Institute. No. 11230144 - 180. Unpublished thesis.

Pytlik A., Pacześniowski K., Rabsztyn J., 2012. Nowa generacja szybkoupustowych dwufunkcyjnych baterii zaworowych do stojaków typu SHC pracujących $w$ warunkach tapań [A new generation of quick-relieve, dual-function valve batteries for hydraulic props type SHC operating in rockbursts hazard conditions]. Wiadomości Górnicze, 1/2012. Wydawnictwo Górnicze Sp. z o.o., Katowice, 678-684.

Pytlik A., Rabsztyn J., 2011: Szybkoupustowa bateria zaworowa do stojaków typu SHC pracujących w warunkach tąań [Quick relief valve batterries for hydraulic props type SHC operating in rockbursts hazard conditions]. Prace Naukowe GIG, Górnictwo i Środowisko, Kwartalnik, 4/2/2011, Górnicze Zagrożenia Naturalne 2011, Człowiek - Zagrożenie i Bezpieczeństwo, Katowice, 416-422.

Shein Y.G., 2002. Dynamiczne obciążenia zmechanizowanej obudowy ścianowej [Dynamic load of powered roof support]. Maszyny Górnicze, R. 20, no. 4. Instytut Techniki Górniczej KOMAG, Gliwice, 39-41.

Sosnica J., 2008. Wptyw doboru wybranych rozwiazań konstrukcyjnych zaworów upustowych na upodatnienie zmechanizowanych hydraulicznych obudów ścianowych [The influence of selected design solutions of relief valve on yielding of powered roof supports]. Doctoral thesis. AGH University of Science and Technology in Krakow. Faculty of Mechanical Engineering and Robotics. Department of Mining Process and Transport Machines, Krakow.

Stoiński K., 1998. Selection of hydraulic prop longwall support for work in conditions of rock mass tremors hazard. Archives of Mining Sciences, 43, 3, 471-486, Kraków. Kraków.

Stoiński K., 2000. Obudowy górnicze w warunkach zagrożenia wstrząsami górotworu [Mining roof support in hazardous conditions of mining tremors]. The Central Mining Institute, Katowice.

Stoiński K., 2008. Praktyczne aspekty upodatnienia obudowy zmechanizowanej [Practcal aspects of powered roof support's yielding]. Napędy i sterowanie, 7/8, Racibórz.

Stoiński K., Pytlik A., 2006. Metody oceny upodatnienia sekcji zmechanizowanej obudowy ścianowej [Assesment method for yielding of a powered roof support]. XIII International Conference on Science and Technology Mining Natural Hazards, 2006. Exploitation depth and mining hazard The Central Mining Institute, Katowice, 337-344.

Szurgacz D., 2011. Próba określenia dynamicznej mocy stojaka zmechanizowanej obudowy ścianowej przeznaczonego do pracy w warunkach zagrożenia wstrzasami górotworu - artykut dyskusyjny [An attempt to determine the dynamic power of powered roof support leg designed to work in hazardous conditions of mining tremors - discussion article]. Central Mining Institute Research Papers. Górnictwo i Środowisko. 1/2011 The Central Mining Institute, Katowice, 79-87.

Szurgacz D., 2013. Zmodyfikowana metoda doboru zmechanizowanej obudowy ścianowej do pracy w warunkach zagrożenia wstrzasami górotworu [A modified method for powered roof support selection to work in hazardous conditions of mining tremors]. Doctoral thesis. The Central Mining Institute, Katowice.

Szweda S., 2001. Loadings of legs in sections of mechanised supports by dynamic movements of roof and floor. Archives of Mining Sciences 46, 3 (2001), 237-266.

Szweda S., 2004. Identyfikacja parametrów charakteryzujących obcią̇enie sekcji obudowy zmechanizowanej spowodowane dynamicznym oddziatywaniem górotworu. [An identification of parameters characterising the load of powered roof support section cause by dynamic impact of rockmass]. Zeszyty Naukowe Politechniki Śląskiej, 1648. Gliwice. 